\title{
ВИНА ЯК КРИМІНАЛЬНО-ПРАВОВА КАТЕГОРІЯ ТА ЇЇ ВПЛИВ НА КВАЛІФІКАЦІЮ ЗЛОЧИНУ
}

\begin{abstract}
Анотація. У статті розкрита сутність та зміст категорії вини, розглянуто їі фрорми і види, а також проаналізовано правозастосовну практику з метою здійснення комплексної розробки питань впливу провини на кваліфікацію злочинів; запропоновані рекомендації щодо вдосконалення кримінального законодавства і практики його застосування. Також висвітлюються концепції винної відповідальності, які існують у вітчизняному кримінальному праві. Розглядаються переваги і недоліки існуючих визначень провини, а також досліджуеться питання, які елементи становлять винне ставлення особи до свого діяння і підлягають обов'язковому доказуванню у кримінальній справі, а які суб'ективні ознаки повинні бути встановлені лише у конкретних випадках.
\end{abstract}

Ключові слова: вина, кримінальна відповідальність, мотив, прямий умисел, суб'єктивна сторона, об’ективна сторона, презумпція.

Lyubavina Victoria University of State Fiscal Service of Ukraine

\section{GUILT AS A CRIMINAL LAW CATEGORY AND ITS IMPACT ON THE QUALIFICATION OF A CRIME}

Summary. The article reveals the essence and content of the category of guilt, considers its forms and types, as well as analyzes law enforcement practice in order to comprehensively develop issues of the impact of guilt on the classification of crimes; proposed recommendations for improving criminal law and practice of its application. The concepts of guilty responsibility that exist in domestic criminal law are also covered. The advantages and disadvantages of the existing definitions of guilt are considered, as well as the question of what elements constitute the guilty attitude of a person to his actions and are subject to mandatory proof in a criminal case, and what subjective features should be established only in specific cases. The author's definitions of direct and indirect intent are aimed at not only the development of theoretical ideas about these types of guilt, but also focused on reducing the distance between theory and law enforcement practice. The system of views on guilt in intentional crimes, formed bathroom as a result of the study: intent, being a mandatory subjective sign of a crime, acts as a private manifestation of the internal component of the crime, partly a clear manifestation of guilt as the core of the subjective side of the crime; guilt in intentional crimes also has its own external "shell", which is expressed in a negative assessment by the court on behalf of the state fourteen va consciously-volitional attitude of a person to the socially dangerous deed and its socially dangerous consequences, which has its own definition divided specificity in various variations of intent; guilt in intentional crimes is the highest social evil, the highest manifestation of immoral behavior; malicious intent is a qualitative property of guilt in intentional steps; grounds for intentional guilt - committed by a person malicious crime; the author's definition of guilt in intentional crimes: guilt intentional crimes - this is a consciously volitional attitude of a person to cothe socially dangerous act committed by him and his socially dangerous consequence, expressed in the form of direct or indirect intent, having received neck negative assessment on behalf of the state.

Keywords: guilt, criminal liability, motive, direct intent, subjective side, objective side, presumption.

$\Pi^{2}$ остановка проблеми. У науці кримінального права тема провини займає важливе місце, оскільки при притягненні до кримінальної відповідальності обов'язковим $є$ врахування не лише об'єктивних ознак діяння, а й психічного ставлення особи до вчиненого. Однак аналіз практики застосування кримінального законодавства про вино свідчить, що цей самостійний обов'язкова ознака складу будь-якого злочину не завжди саме так оцінюеться слідчими та судовими органами.

Складнощі, пов'язані із застосуванням норм про вину, викликані не недостатністю досліджень в цій області або зневагою до неї з боку сучасної кримінально-правової науки, а обумовлені іншими причинами. Зокрема домінуючою протягом останніх десятиліть і отримала вираз в чинному Кримінальному кодексі теорії провини притаманне сприйняття суб'єктивних ознак як абстрактної конструкції.

Вина досить часто розглядається як незалежний від об'єктивних елементів інститут криміналь- ного права, що базується на індивідуальному переживанні особи, яка скоїла злочин. Відповідно, багато суперечок про вину залишають поза зоною уваги питання застосування положень теорії до конкретних діянь і слідчих ситуащій, а пропоновані авторами теоретичні конструкщії не можуть бути точно відображені в судовій і слідчій діяльності.

Аналіз останніх досліджень і публікацій. За останні роки було написано і опубліковано ряд монографрічних робіт, присвячених дослідженню різних аспектів провини і їі форм, таких авторів як С. В. Векленко, А. В. Гребенюк, І. А. Гревнова, С. В. Дубовіченко, С. А. Іванов, В. В. Місяці, В. А. Нерсесян, С. В. Скляров, І. М. Тяжкова. Однак комплекс проблем, пов'язаних з встановленням суб'єктивних ознак, порушувалося лише на початку 70-х рр. минулого століття в декількох роботах П. С. Дагель, Д. П. Котова і Р. І. Міхеєва.

Вина, будучи в теорії кримінального права обов'язковою ознакою складу злочину, часто виявляеться недооціненою при попередньому і су- 
довому розслідуванні. Розробка зазначеної теми обумовлена важливістю подолання існуючого помітного розриву між теорією і практикою застосування законодавства про вину.

Ціль статті полягає в тому, щоб на основі комплексного аналізу правових норм, теоретичних положень і практики застосування законодавства про вину сформулювати пропозиції i рекомендації, що дозволяють забезпечити верховенство принципу суб'єктивного поставлення.

Виклад основного матеріалу дослідження. У 40-50-х роках у вітчизняній кримінальноправовій доктрині активно розвивалася оцінна теорія провини, відповідно до якої вина існуе як оцінка судом всіх обставин, пов'язаних зі злочином і особистістю злочинця. В результаті дискусії 50-х років вона була відкинута на користь психологічного розуміння провини, домінуючого по теперішній час в науці кримінального права.

Проблематика полягає в тому, що вина не може бути пізнана за допомогою існуючих засобів і методів, а значить, вина зобов'язання включає в себе оціночні елементи. Їх ілюстрацією може бути інститут присяжних засідателів і основний принцип оцінки доказів у кримінальному процесі - за внутрішнім переконанням слідчого, особи, яка провадить дізнання, прокурора і суду.

Вважається, якщо «вина» - матеріально-правова категорія, то «винуватість» - процесуально-правова, вторинна для континентального права, яку слід пізнати в регламентованому правовому процесі з певними стадіями та процедурами [1, с. 15].

Слід відмітити, що у сучасній вітчизняній теорії кримінального права і Кримінальному кодексі України саме психологічне розуміння провини має велике значення, оскільки дозволяє абсолютно чітко визначити вину як самостійну суб'єктивну підставу кримінальної відповідальності і вимагає від суду встановлювати дійсне ставлення особи до вчиненого і його наслідків.

Вина - це психічне ставлення особи у формі умислу і необережності до здійснюваного їм суспільно небезпечного діяння і до його наслідків. Зміст вини утворюеться двома елементами психічної діяльності людини - свідомістю і волею, які характеризуються інтелектуальними і вольовими складовими процесу психічної діяльності людини під час вчинення злочину. Ці складові іменуються інтелектуальним і вольовим елементами (моментами) провини [3, с. 5].

Таким чином, в юридичній науці питання співвідношення понять «вина» $\mathrm{i}$ «винність» як і раніше носить дискусійний характер, до сих пір не вироблено единої думки з цієї проблеми, що, на наш погляд, ускладнюе можливості категоріального апарату в теорії права з вироблення дефініцій.

Узагальнюючи розглянуті точки зору, висловимо власну думку по даному питанню. По-перше, вважаємо, що термін «винність»: а) не тотожний «вини»; б) використання його в праві обумовлено необхідністю доведення провини; в) його не слід включати в об'єктивну сторону правопорушення, так як в тій чи іншій мірі підлягае доведенню; вона пов'язана 3 психічним станом і ставленням до скоєного суб'єкта. По-друге, відзначимо, що для визнання винності суб'єкта необхідні: фракт вчинення діяння, яке відповідає юридичним критеріям правопорушення; наявність суб'єкта, що відповідає юридичним критеріям правопорушника; повинна бути визначена форма провини; дана негативна оцінка діяння юрисдикційних органах; винесено і вступило в силу рішення про притягнення до відповідальності.

Вина у вчиненні правопорушення реалізована через поняття винності, про яке щойно писали, тому можна говорити про те, що правопорушення і вина нерозривно пов'язані, що підтверджуеться в конструкції складу правопорушення, що включає в себе традиційно чотири елементи - об'єкт, суб'єкт, об'єктивну і суб'єктивну сторони.

Хотілося б звернути увагу на те, що хоча законодавець ототожнюе провину в першу чергу з наміром і необережністю, статті Загальної та Особливої частин Кримінального кодексу України дозволяють позначити цілий перелік психічних процесів, які впливають на кваліфікацію у відповідних випадках: мотиви, спонукання, цілі, емоції, добровільність, відсутність добровільності - вимушеність, несподіванка.

У науці кримінального права можна виділити три підходи до того, які 3 перерахованих психічних компонентів складають поняття вини. Панівною в даний час $є$ точка зору, згідно з якою вина - це обов'язковий в будь-якому складі, але лише один 3 низки ознак суб'єктивної сторони злочину, до яких також відносяться фракультативні ознаки - мотив, мета і іноді емоції.

Слід зауважити, що саме поділ провини, мотивів i цілей викликане об'єктивними потребами теорії кримінального права. Однак поділ суб'єктивної сторони на обов'язкову ознаку - провину і фракультативні - мотиви і цілі, є умовним, заснованим на фрормальних положеннях. Вина, мотиви і цілі нерозривно пов'язані. Правильна кваліфікація злочину і диференціація покарання неможливі без співвіднесення мотивів і цілей 3 іншими обов'язковими ознаками елементів складу.

Важливо, що емощї і афрект, накладаючи певне забарвлення на інтелектуальні та вольові процеси, що протікають в психіці винного, характеризують суб'єктивну сторону діяння, а не особистість злочинця, оскільки можуть бути і не властиві його звичайній поведінці. Також вказуеться, що поділ психологічних характеристик на ознаки і технічні прийоми штучний.

Те саме можна сказати і щодо несподіванки, вимушеності і добровільності. Отже, вони повинні бути визнані факультативними ознаками суб'єктивної сторони злочину.

В сучасній теорії кримінального права співіснують дві точки зору на питання про кількість ознак, які підлягають встановленню по кримінальній справі в залежності від конструкщії об'єктивної сторони. Перша передбачає необхідним і достатнім встановлення в формальних складах тільки усвідомлення суспільної небезпеки і характеру свого діяння. Друга вимагає також довести фракт бажання вчинення діяння. В роботі аргументується, що формула, додатково включає бажання зробити діяння, має низьку практичну цінність.

На основі аналізу точок зору різних авторів, а також узагальнення судової практики можна зробити висновок, що виключення протиправності з формули умисної вини іноді призводить до винесення об'єктивно несправедливих обвинувальних вироків. 
Слід звернути увагу на те, що теорія кримінального права для зазначених випадків дозволяе оперувати поняттям «помилка в протиправності». Однак наукових досліджень щодо помилки і її релевантності до конкретних випадків небагато і в них висловлюються часто діаметрально протилежні думки. Аргументується, що презумпщія знання кримінального закону не повинна застосовуватися, якщо мова йде про некримінальних протиправності (вираженої з допомогою бланкетной диспозищіі), оскільки така форма конструювання статті передбачає зниження знання про заборону.

Важливе значення в понятті вини мають і такі її елементи, як форма і ступінь вини. Форми вини - це зазначені в кримінальному законі сполучення певних ознак свідомості і волі особи, що вчиняе суспільно небезпечне діяння. У сполученні таких ознак і виражаеться психічне ставлення особи до діяння і його наслідків. Чинне кримінальне законодавство виділяе дві форми вини - умисел і необережність [4, с. 24].

У теорії кримінального права переважае точка зору, згідно з якою, якщо доведено, що винний діяв з прямим умислом, то він підлягає відповідальності у відповідності до змісту і спрямованістю наміру, а якщо з непрямим, то відповідно до фактично настали шкідливими наслідками. А також, що замах на злочин можливо тільки з прямим умислом.

При прямому умислі особа бажае настання суспільно небезпечних наслідків, а при непрямому - не бажає, але свідомо припускае їх настання. Бажання означае, що особа цілеспрямовано діе в напрямку досягнення тих суспільно небезпечних наслідків, досягнути яких вона поставила собі за мету [3, с. 53].

А. В. Гребенюк в обгрунтування самостійного існування подвійної форми вини на рівні з умислом та необережністю стверджуе, що діяння, які вчиняються 3 подвійною формою вини, мають складну структуру об’ективної сторони: завжди мають місце віддалені суспільно небезпечні наслідки, тяжкість яких $е$ значно вищою у порівнянні з наслідками найближчого характеру, при цьому наслідки найближчого характеру надають новий імпульс розвитку причинного зв'язку та сприяють настанню більш тяжких суспільно небезпечних наслідків [5, с. 137].

Проте, у теорії кримінального права та правозастосовній практиці немае едності щодо так званої змішаної форми вини [6, с. 97].

Тільки відносно лише менш ніж десяти складів (вбивство, заподіяння шкоди здоров'ю, розкрадання і деякі склади, які є спеціальними по відношенню до перерахованих вище), а також відповідних їм кваліфрікуючих ознак інших складів існуе можливість розмежування прямого і непрямого умислу. На основі аналізу судової практики у справах про вбивство і заподіяння шкоди здоров'ю полягае, що навіть до них не завжди застосовні кваліфікаційні правила про відповідальності в залежності від виду наміру і про неможливість замаху з непрямим.

Висновки. Підводячи деякий підсумок сказаному, слід зазначити, що визначення вини в кримінальному законі повинно відповідати законодавчій моделі наміру і необережності. Як уже зазначалося, у визначенні форм провини йдеться про психічні і соціально-психічні ознаки цих явищ.
Кримінально-правова категорія «вина» $e$ ядром суб'єктивної сторони. Кримінально-правова кваліфікація неможлива без однакового розуміння провини. У зв'язку з цим необхідно торкнутися питання про легальне визначення провини. Тільки на основі комплексного підходу можна сформулювати поняття провини і винності, застосовані, за деякими винятками, у всіх copepax правового регулювання, i охарактеризувати основні параметри інституту провини. Отже, вина - це психічне ставлення деліктоздатної фрізичної особи або особи, уповноваженої на вчинення юридично значущих дій від імені та в інтересах юридичної особи, до здійснюваного їм суспільно шкідливого діяння і його наслідків, в якому проявляеться його негативне суб'єктивне ставлення до цінностей суспільства.

Таким чином, категорія вини пов'язуе воедино уявлення про підстави, межі і цілі кримінальної відповідальності, $е$ необхідною ланкою в усвідомленні його місця в системі соціального контролю, служить найважливішою фрілософською передумовою обгрунтування необхідності і меж регулятивного впливу кримінального права на суспільне життя.

Вагоме місце в системі знань про вину займає вина умисна, яку можна розглядати як її підсистему. У науковій дискусії недоцільно замикатися в рамках загального поняття провини, а також обмежуватися лише одним позиціонуванням провини навмисної. У зв'язку з цим виникае об'єктивно виправдана науково-прикладна потреба розгляду умисної вини через призму психолого-оціночної концепції, потреба в новій постановці питання про умисну вину - як про вину в умисному злочині, що сучасному українському суспільству гостро необхідна нова кримінальноправова теорія, розвиток якої повинен мати еволюційний характер. Однак не можна приймати поспішних рішень, сліпо слідувати західноевропейським канонам, необхідно 3 повагою ставитися до традицій вітчизняного кримінального права. Тому важливо зберегти в кримінальному законодавства принцип вини, ознака злочину «винність", конструювання і просто сама згадка в кримінальному законі умисла і його видів.

Вина мае двоедине начало: 1) внутрішня складова злочину, ядро його суб'єктивної сторони, що знаходить втілення в намірі або необережності, і 2) зовнішня "субстанція» у вигляді негативної оцінки суду від імені держави усвідомлено-вольового ставлення особи до здійснюваного їм суспільно небезпечного діяння і його суспільно небезпечного наслідку.

Підставою виникнення провини слід визнати вчинений особою злочин. Зміст вини наповнений об'єктивними і суб'єктивними ознаками злочину. Намір, будучи обов'язковою суб'єктивною ознакою злочину, виступає приватним проявом внутрішньої складової злочину, проявом провини як ядра суб'єктивної сторони злочину.

Разом $з$ тим, вина в умисних злочинах мае і свою зовнішню «оболочку», що знаходить вираз у негативній оцінці судом від імені держави усвідомлено-вольового ставлення особи до здійснюваного їм суспільно небезпечного діяння та ії суспільно небезпечного наслідку, що мае свою специфіку в різних варіаціях наміру. 


\section{Список літератури:}

1. Вереша Р. В. Поняття вини як елемент змісту кримінального права України : авторед. дис. ... канд. юрид. наук : 12.00.08. ; Київ. нац. ун-т імені Тараса Шевченка. Київ, 2004. 20 с.

2. Чернишова Н.В. Кримінальне право України: Загальна частина : підручник. Київ : Атіка, 2003. С. 119.

3. Кудрявцев В.Н.Мотивы преступного поведения. Юридическая психология. 2012. № 4. С. $2-7$.

4. Науково-практичний коментар Кримінального кодексу України від 5 квітня 2001 року / За ред. М.I. Мельника, М.І. Хавронюка. Київ : Каннон, А.С.К., 2002. 874 с.

5. Гребенюк А.В. Вина в российском уголовном праве : дис. на соискание учен. степени канд. юрид. наук : спец. 12.00 .08 «Уголовное право и криминология; уголовно-исполнительное право». Москва, 2004. 195 с.

6. Шевченко Є.В. До питання змісту і співвідношення понять «змішана», «подвійна» і «складна форма вини» в кримінальному праві. Проблели законності. 2011. № 115. URL: http://cyberleninka.ru/article/n/k-voprosusoderzhaniya-i-sootnosheniya-ponyatiy-smeshannaya-dvoynaya-i-slozhnaya-formaviny-v-ugolovnom-prave-1

\section{References:}

1. Veresha R.V. (2004) Poniattia vyny iak element zmistu kryminal'noho prava Ukrainy: vtoref. dys. ... kand. iuryd. nauk: 12.00.08.; Nats. un-t imeni Tarasa Shevchenka. Kyiv. (in Ukrainian)

2. Chernyshova N.V. (2003) Kryminalne pravo Ukrainy: Zahalna chastyna: pidruchnyk. Kyiv: Atika. (in Ukrainian)

3. Kudriavtsev V.N. (2012) Motyvy prestupnoho povedenyia. Yurydycheskaia psykholohyia, no. 4, pp. 2-7.

4. Mel'nyk M.I., Khavroniuk M.I. (2002) Naukovo-praktychnyj komentar Kryminal'noho kodeksu Ukrainy. Kyiv: Kannon, A.S.K. (in Ukrainian)

5. Hrebeniuk A.V. (2004) Vyna v rossyjskom uholovnom prave: dys. na soyskanye uchen. stepeny kand. iuryd. nauk.: spets. 12.00 .08 «Uholovnoe pravo y krymynolohyia; uholovno-yspolnytel'noe pravo». Moscow. (in Russian)

6. Shevchenko Ye.V. (2011) Do pytannia zmistu i spivvidnoshennia poniat' "zmishana», "podvijna» i «skladna forma vyny» v kryminal'nomu pravi. Problemy zakonnosti, no. 115. URL: http://cyberleninka.ru/article/n/k-voprosusoderzhaniya-i-sootnosheniya-ponyatiy-smeshannaya-dvoynaya-i-slozhnaya-formaviny-v-ugolovnom-prave-1 (in Ukrainian) 